\title{
MICROSPATIAL STRUCTURE OF THE SEED BANK OF XEROTHERMIC GRASSLAND - INTRACOMMUNITY DIFFERENTIATION
}

\author{
JOANNA CZARNECKA \\ Department of Ecology, Institute of Biology \\ Maria Skłodowska-Curie University \\ Akademicka 19, 20-033 Lublin, Poland \\ e-mail: jcieszko@biotop.umcs.lublin.pl \\ (Received: January 6, 2003. Accepted: March 11, 2004)
}

\begin{abstract}
The study analyses the quantity and spatial structure of the seed bank of the xerothermic grassland located in the Biała Góra near Tomaszów Lubelski (Central Roztocze Region). The seed stock of the bank was compared with the vegetation found in two different patches of the examined grassland. The number of seeds per square meter was estimated at 5328 and 5355, depending on the patch. The seed bank's spatial organisation is clustered. The most important factors determining this spatial distribution are: remaining of the seeds in close vicinity of parent plants, and the "group" dispersal of the seeds and fruits.
\end{abstract}

KEY WORDS: seed bank, spatial structure, species diversity, xerothermic grassland.

\section{INTRODUCTION}

According to Thompson at al. (1997) the seed banks of different types of grasslands are quite well examined. However, the majority of these data comes form managed grasslands - most often by grazing and hay-making. There are few data from limestone, xerothermic grasslands from the area of Western Europe (e.g. Schenkeveld, Verkaar 1984; Milberg, Hansson 1994; Willems 1995), and there are no data on the soil seed bank of this type of plant community in Polish literature at all.

This work is the attempt to fill this gap. The aim of the study was to learn the seed bank structure of xerothermic grassland and to investigate the relationship between the vegetation and soil seed bank. Another investigated problem was the spatial horizontal structure of the seed bank. There is little information about it (Thompson 1986; Chabrerie et al. 2002), in contrast to a lot of data about the vertical distribution of seeds in the soil profile in different plant communities (e.g. Symonides 1978; Pirożnikow 1983; Grandin, Rydin 1998; Edwards, Crawley 1999). The answer to the question about the spatial structure of the xerothermic grassland seed bank and the agents responsible for it can be very helpful for the methodology of seed bank investigations and the evaluation of the number of diaspores in soil. Spatial distribution of diaspores is independent from vegetation structure (Chabrerie et al. 2002). This was often the situation when despite the apparent homogeneity of the sampling area there occurred large differences in the distribution and abundance of species in the seed bank among sampling locations (Gross 1990).

\section{STUDY SITE}

The research was carried out at the Biała Góra, a hill of altitude $349 \mathrm{~m}$ a. s. 1., situated in the south-eastern part of Roztocze Tomaszowskie (geographical classification according to Buraczyński 1997), about $5 \mathrm{~km}$ away from Tomaszów Lubelski. The part of Biała Góra was established as an ecological unit in 1996 because of the unique value of this area.

The parent rocks of the soils of the mountain are chalk marls and loess. Shallow alkaline and neutral cretaceous fertile soils have been formed there (Czarnecka 1994). The largest part of the southern and south-western slopes are overgrown with xerothermic grassland of the alliance Cirsio-Brachypodion pinnati Hadač et Klika 1944 (classification of plant communities after Matuszkiewicz 2001). Lower and higher patches which constitute the mosaic vegetation can be observed there. Lower patches of grassland with lesser plant density are characterised by high abundance of the following species: Aster amellus, Teucrium chamaedrys, Carex transsilvanica, Euphorbia cyparissias 
and Scabiosa ochroleuca (nomenclature of species after Mirek et al. 2002). One species - Brachypodium pinnatum - dominates in higher, denser patches, as well. B. pinnatum is accompanied by: Linum flavum, Salvia verticillata and $S$. pratensis. One species included into "The Polish Red Data Book of Plants" is observed there: it is Senecio macrophyllus with the VU (vulnerable) category of threat (Czarnecka, Kucharczyk 2001).

The brushwood of the Rhamno-Prunetea Rivas Goday et Garb. 1961 class constitutes the border between the grassland and the forest. This brushwood makes the belt of vegetation adjacent to the forest with dominance of Carpinus betulus, accompanied by Fagus sylvatica, Populus tremula, Tilia cordata and Pinus sylvestris (Czarnecka 1994, 1995).

\section{METHODS}

Two study plots $(3 \times 3 \mathrm{~m})$ were established in May 1999:

Plot $\mathrm{A}-$ in the patch of lower grassland with the dominance of $A$. amellus,

Plot B - in the patch of higher grassland with the dominance of $B$. pinnatum.

All blossoming and fruiting individuals within the borders of the study plots were counted during the entire vegetative season. One hundred soil samples $(5 \mathrm{~cm}$ deep, 100 $\mathrm{ml}$ volume, 1 sample per $100 \mathrm{~cm}^{2}$ ) were taken from the central square of both plots in November. The samples were washed separately on a $0.25 \mathrm{~mm}$ sieve. All seeds were picked from the remaining part of the material under 10x magnification and identified. The most abundant seeds were sown into the soil and were kept in the greenhouse for 2 months under conditions thought to promote germination.

To check the relationship between parent plants distribution and spatial structure of the seed bank, individuals of the following species were selected: Melilotus officinalis, S. macrophyllus, L. flavum, and S. verticillata. They were chosen in such a way so that the next neighbouring individual could not be closer than $6 \mathrm{~m}$. The individuals of the above listed species do not establish dense agglomerations, which helped to find isolated examples. Two lines at the angle $90^{\circ}$ between them from each individual towards the bottom of the hill were established. Soil samples along the lines were taken at distances of 10, 20, 30, 40, 50, 60, 80, $100,130,170,200,230,270$, and $300 \mathrm{~cm}$ from chosen plants (28 samples per each species). The treatment procedure of the samples was the same as above.

\section{Statistical analysis}

The similarity coefficient between vegetation and the seed bank was calculated according to the formula (Szafer, Zarzycki 1972):

$$
P=50 \times\left(\frac{c}{a}+\frac{c}{b}\right) \%
$$

where:

$\mathrm{a}$ - the number of species in vegetation,

$\mathrm{b}$ - the number of species in the seed bank,

$\mathrm{c}-$ the number of species in common.

Variation region (Sobczyk 1990) is the result of subtraction of the highest and lowest seed number of the particular species.
To evaluate the spatial structure of the seed bank of each species variance $\left(\mathrm{s}^{2}\right)$ to mean $(\mathrm{m})$ ratio (Kershaw 1978) and the relation of mean and Lloyd's mean crowding $\left(\mathrm{m}^{*}\right)$ were used (Lloyd 1967; Dessaint et al. 1991). Mean crowding was calculated according to the following formula:

$$
\mathrm{m}^{*}=\frac{\sum_{\mathrm{i}=1}^{\mathrm{Q}} \mathrm{x}_{\mathrm{i}}\left(\mathrm{x}_{\mathrm{i}}-1\right)}{\sum_{\mathrm{i}=1}^{\mathrm{Q}} \mathrm{x}_{\mathrm{i}}}
$$

where:

$\mathrm{X}_{\mathrm{i}}$ - the number of seeds in $\mathrm{i}$-th core,

$\mathrm{Q}$ - the number of cores.

Relations significantly higher then 1 indicate aggregated spatial structure (Dessaint et al. 1991).

To evaluate biodiversity of the seed bank the following coefficients were used: total species diversity - and evenness - E (Krebs 1996; Olaczek, Warcholińska 1999), which were calculated according to the formulae:

$$
\overline{\mathrm{H}}=-\sum\left(\frac{\mathrm{n}_{\mathrm{i}}}{\mathrm{N}}\right) \log _{2}\left(\frac{\mathrm{n}_{\mathrm{i}}}{\mathrm{N}}\right) ; \mathrm{E}=\frac{\overline{\mathrm{H}}}{\log _{2} \mathrm{~S}}
$$

where: $n_{i}-$ the number of seeds of $i$-th species,

$\mathrm{N}$ - the total number of seeds,

$\mathrm{S}$ - the total number of species.

Both indices are thought to be useful to analyse changes of diversity of one plant community in time and in space (Kwiatkowska, Symonides 1985).

Minimal detectable seed density (D) per square meter and litre was calculated as follows (Thompson et al. 1997):

$$
\mathrm{D}>\ln (20) \times(\mathrm{Q} \times \mathrm{A})
$$

where:

$\mathrm{A}$ - the area of each core in $\mathrm{m}^{2}$ or the volume in litres,

$\mathrm{Q}$ - the number of soil cores.

\section{RESULTS}

\section{Structure of the seed bank}

2100 seeds were found in the soil; 2095 of them were classified as species or genus (49 taxa together); the five remaining seeds were categorised as merely belonging to the Poaceae family. The number of diaspores within both patches of grassland was almost identical: 1048 of them came from the soil seed bank of the lower patch of grassland (plot A), and 1052 - from the higher patch (plot B).

Up to $73 \%$ of all the seeds found in the lower grassland patch (A) belongs to four most numerous species (Medicago lupulina, Hypericum perforatum, A. amellus and Betula pendula). In the higher grassland patch (B) the three most numerous species were $B$. pinnatum, $H$. perforatum and Origanum vulgare; together they constitute $70 \%$ of all the diaspores.

Despite the fact that the average number of seeds per square meter is similar for both vegetation types (5328 for the lower grassland patch vs. 5255 for the higher one), considerable differences were noticed in species composition of the seed bank, as well as in the occurrences of particular species (Table 1). 20 common species were found in the 
TABLE 1. Vegetation (number of shoots per plot) and seed bank structure (number of seeds per $\mathrm{m}^{2}$ ) of two different patches of grassland.

\begin{tabular}{|c|c|c|c|c|}
\hline \multirow{2}{*}{ Taxa } & \multicolumn{2}{|c|}{ Plot A } & \multicolumn{2}{|c|}{ Plot B } \\
\hline & Vegetation & Seed bank & Vegetation & Seed bank \\
\hline \multicolumn{5}{|l|}{ Present in vegetation and in the seed bank } \\
\hline Agrimonia eupatoria $\mathrm{L}$. & 2 & 10 & 26 & 5 \\
\hline Aster amellus L. & 320 & 718 & 7 & 25 \\
\hline Brachypodium pinnatum (L.) P. Beauv. & - & - & 1480 & 1442 \\
\hline Campanula rapunculoides $\mathrm{L}$. & - & - & 2 & 5 \\
\hline Cichorium intybus $\mathrm{L}$. & 3 & 49 & - & - \\
\hline Coronilla varia $\mathrm{L}$. & - & - & 2 & 5 \\
\hline Daucus carota L. & 1 & 5 & - & 5 \\
\hline Echium vulgare L. & 1 & 15 & - & - \\
\hline Euphorbia cyparissias $\mathrm{L}$. & 46 & 138 & - & 148 \\
\hline Galium mollugo L. & 49 & 377 & 5 & 71 \\
\hline Leucanthemum vulgare Lam. & 17 & 10 & - & - \\
\hline Linum catharticum $\mathrm{L}$. & 1 & 204 & - & - \\
\hline Linum flavum $\mathrm{L}$. & 1 & 25 & 23 & 265 \\
\hline Medicago lupulina $\mathrm{L}$. & 17 & 1697 & - & 15 \\
\hline Melampyrum arvense $\mathrm{L}$. & 19 & 5 & - & - \\
\hline Peucedanum cervaria (L.) Lapeyr. & - & - & 2 & 5 \\
\hline Picris hieracioides L. & 2 & 92 & - & 25 \\
\hline Pimpinella saxifraga $\mathrm{L}$. & 5 & 76 & - & - \\
\hline Plantago media $\mathrm{L}$. & 1 & 5 & - & - \\
\hline Poaceae & 1 & 15 & - & 10 \\
\hline Ranunculus bulbosus L. & 1 & 5 & - & 5 \\
\hline Salvia sp. & 7 & 25 & 26 & 15 \\
\hline Scabiosa ochroleuca $\mathrm{L}$. & 7 & 143 & 1 & - \\
\hline Solidago virgaurea $\mathrm{L}$. & - & - & 2 & 31 \\
\hline Teucrium chamaedrys $\mathrm{L}$. & 3 & - & - & 275 \\
\hline Trifolium alpestre L. & - & - & 2 & 25 \\
\hline Vicia cracca $\mathrm{L}$ & 6 & 5 & - & - \\
\hline \multicolumn{5}{|l|}{ Present only in the seed bank } \\
\hline Anagallis arvensis L. & - & 15 & - & - \\
\hline Arenaria serpyllifolia $\mathrm{L}$. & - & 5 & - & 25 \\
\hline Betula pendula Roth. & - & 601 & - & 158 \\
\hline Carex digitata $\mathrm{L}$. & - & 5 & - & 5 \\
\hline Carex transsilvanica Schur & - & - & - & 15 \\
\hline Cerinthe minor $\mathrm{L}$. & - & 81 & - & 438 \\
\hline Chenopodium album $\mathrm{L}$. & - & 5 & - & - \\
\hline Conyza canadensis (L.) Cronquist & - & - & - & 5 \\
\hline Euphorbia helioscopia L. & - & 5 & - & 10 \\
\hline Fragaria viridis Duchesne & - & - & - & 5 \\
\hline Galium boreale $\mathrm{L}$. & - & 5 & - & 5 \\
\hline Hypericum perforatum $\mathrm{L}$. & - & 866 & - & 1248 \\
\hline Melilotus officinalis (L.) Pall. & - & 10 & - & - \\
\hline Origanum vulgare L. & - & 76 & - & 1024 \\
\hline Salix sp. & - & - & - & 5 \\
\hline Sanguisorba minor Scop. & - & 15 & - & 20 \\
\hline Sanicula europaea $\mathrm{L}$. & - & - & - & 5 \\
\hline Senecio macrophyllus M. Bieb. & - & 5 & - & - \\
\hline Thymus pulegioides L. & - & - & - & 5 \\
\hline Trifolium repens $\mathrm{L}$. & - & 10 & - & - \\
\hline Urtica dioica $\mathrm{L}$. & - & 5 & - & - \\
\hline Viola sp. & - & - & - & 5 \\
\hline \multicolumn{5}{|l|}{ Present only in vegetation } \\
\hline Medicago falcata $\mathrm{L}$. & 11 & - & - & - \\
\hline Total number of shoots and seeds & 521 & 5328 & 1578 & 5355 \\
\hline Number of taxa & 22 & 35 & 12 & 34 \\
\hline
\end{tabular}

soil coming from both study plots, but only one of them, $H$. perforatum, is characterised by a similar quantity.

The analysed area, together with the volume of the soil, allowed for the detection of the species whose density reached at least 15 per square meter $(0.3$ per litre, assuming $95 \%$ confidence level).
The results of the seed germination test are presented in Table 2.

The seed bank of the examined xerothermic grassland clearly exhibits the clustered spatial structure (Figs 1-2), which is indicated by the diversity of the number of diaspores in particular samples. The total seed number in the 
TABLE 2. Seed germination test results.

\begin{tabular}{lrr}
\hline \multirow{2}{*}{ Species } & \multicolumn{2}{c}{$\begin{array}{c}\text { Percentage of germinative seeds } \\
\text { (number of seeds tested in parentheses) }\end{array}$} \\
\cline { 2 - 3 } & \multicolumn{1}{c}{ Plot A } & Plot B \\
\hline Aster amellus & $52.3(132)$ & - \\
Betula pendula & $1.6(123)$ & $3.6(28)$ \\
Brachypodium pinnatum & - & $80.8(287)$ \\
Cerinthe minor & $18.7(16)$ & $1.2(80)$ \\
Euphorbia cyparissias & $3.8(26)$ & $0.0(29)$ \\
Galium mollugo & $0.0(69)$ & $7.0(14)$ \\
Hypericum perforatum & $32.5(163)$ & $15.2(244)$ \\
Linum catharticum & $8.3(36)$ & - \\
Linum flavum & - & - \\
Medicago lupulina & $18.5(325)$ & - \\
Origanum vulgare & $13.3(15)$ & - \\
Picris hieracioides & $43.5(23)$ & - \\
Pimpinella saxifraga & $76.9(13)$ & $2.0(185)$ \\
Scabiosa ochroleuca & $80.0(20)$ & - \\
Teucrium chamaedrys & - & $29.2(966)$ \\
\hline Total over all species & $23.9(961)$ & \\
\hline
\end{tabular}

\section{All seeds}

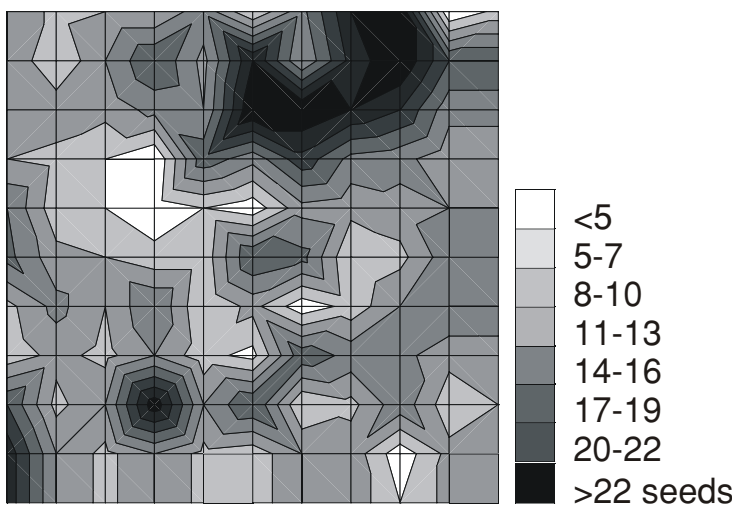

samples coming from the lower grassland patch (A) ranges from 1 to 52; in the samples of the higher patch (B) - from 3 to 22 . The empirical variation region for particular species reaches the following values: $B$. pinnatum $-15, M$. lupulina $-52, H$. perforatum -6 (A) and 7 (B), O. vulgare - 1 (A) and 6 (B), and for B. pendula -6 (A) and 3 (B).

Moreover, the relatively high values of the variance to mean ratio $\left(\mathrm{s}^{2} / \mathrm{m}\right)$, and Lloyd's mean to mean crowding ratio (Table 3, Fig. 3) point to the clustered spatial structure, as well. For the analysis I chose the species whose average number of seeds per sample was higher than 0.2. In plot A only the seeds of Euphorbia cyparissias are distributed in the manner close to random $\left(\mathrm{s}^{2} / \mathrm{m}=0.89\right.$; $\left.\mathrm{m}>\mathrm{m}^{*}\right)$. The remaining species $\left(\mathrm{s}^{2} / \mathrm{m}>1 ; \mathrm{m}<\mathrm{m}^{*}\right)$ clearly exhibit the clustered spatial structure.

The most important reason for the detected spatial structure of the seed bank seems to be the fact that most of the seeds remain in close vicinity of the parent plant. This observation refers not only to the barochorous species, although in this particular case this relationship is even

Fig. 1. Spatial structure of the seed bank - patch of lower grassland with dominance of Aster amellus (plot A).

\section{Medicago Iupulina}

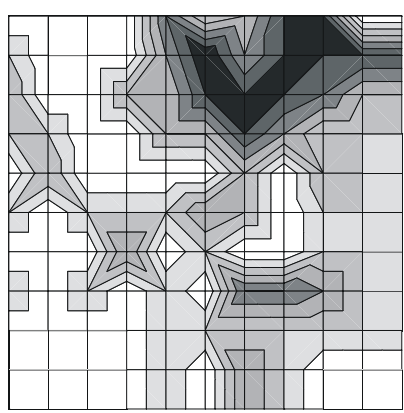

\section{Betula pendula}

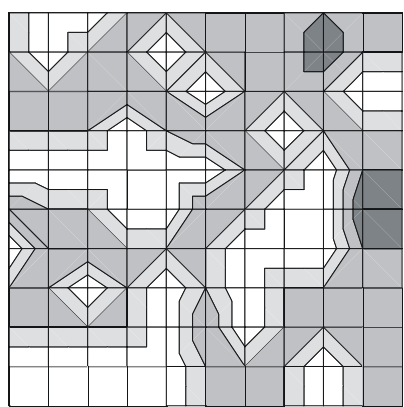

Aster amellus

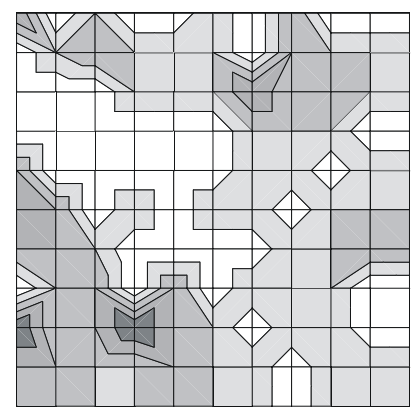

\section{Hypericum perforatum}

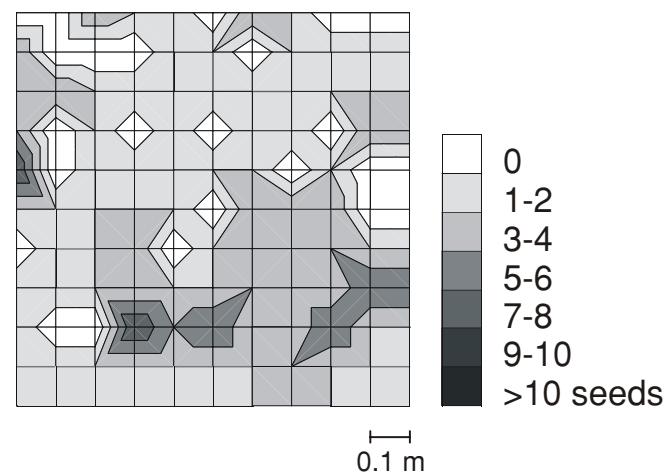




\section{All seeds}



$<5$

$5-7$

8-10

$11-13$

$14-16$

17-19

20-22 seeds

\section{Brachypodium pinnatum}

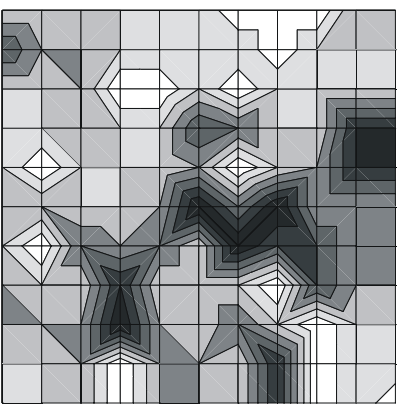

\section{Origanum vulgare}

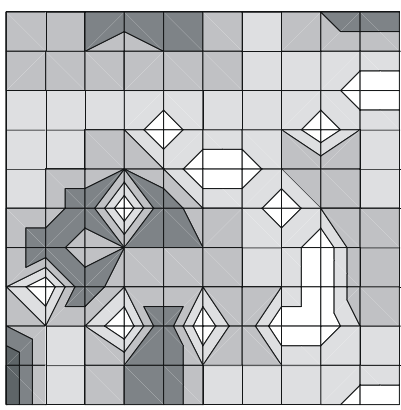

Fig. 2. Spatial structure of the seed bank - patch of higher grassland with dominance of Brachypodium pinnatum (plot B).

\section{Hypericum perforatum}

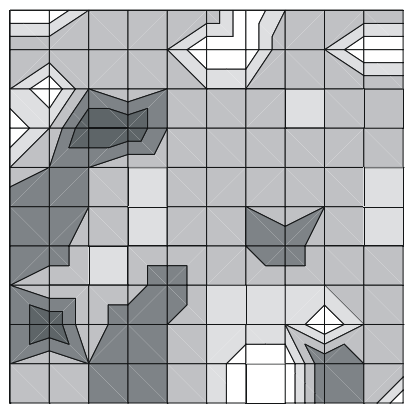

\section{Cerinthe minor}

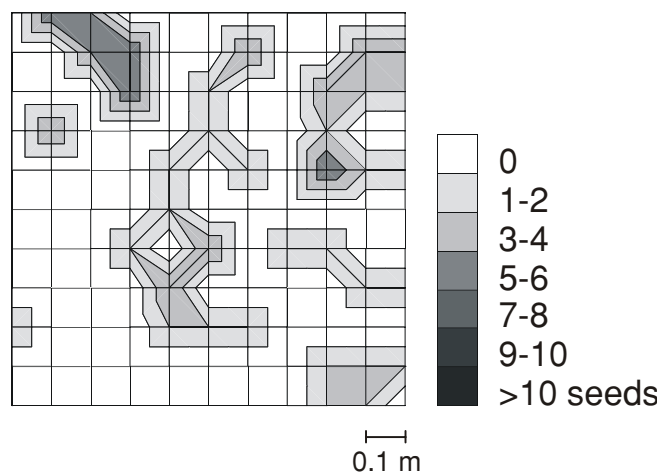

more evident (e.g. L. flavum, M. officinalis and S. verticilla$t a)$, but it is equally true for anemochorous species, e.g. $S$. macrophyllus (Fig. 4). Another reason for this spatial structure is the "group" seed dispersal of some species. A good example is the coming off of whole heads of A. amellus, the dispersal of fruits containing several seeds within them or grown together dry fruits (Sanguisorba minor, Cerinthe minor or Plantago media), or flower calyxes with fruits of Teucrium chamaedrys, O. vulgare and S. verticillata.

\section{Biodiversity of the seed bank}

Mean values of biodiversity coefficient for both vegetation types are similar (1.83 for A and 1.90 for plot B), and their spatial structure also indicates the clustered spatial structure of the seed bank. The value of the evenness coefficient for the lower grassland is also only slightly lower than for the higher patch ( 0.85 for A and 0.88 for plot B).

Values of both coefficients vary strongly in space. This fact results first of all from the spatial distribution of the seeds of the species dominating in both areas: $M$. lupulina (A) and B. pinnatum (B). The areas with high numbers of these species, and their ample participation, are characterised by considerable lowering of both biodiversity and evenness coefficient (Figs 5-6).

\section{Vegetation versus the seed bank}

A relatively strong similarity was noticed between vegetation composition and seed bank. The similarity coefficient reached $74 \%$ for the lower grassland (plot $\mathrm{A}$ ), and $62 \%$ for the higher patch (plot B). In the vegetation of the plot A 22 plant species were present, while in soil the seeds of 35 taxa were found ( 20 of them common). For the B area these numbers are 12,34 and 11 , respectively. The seeds of almost all the species present in the plant cover are to be found in the seed bank, too. However, some of the taxa, numerous in the seed bank, are characterised by a very small presence in vegetation, or they are even totally absent. Only A. amellus in the A area and B. pinnatum in B 
TABLE 3. Spatial structure of the seed bank - numerical characteristics; $\mathrm{m}-$ mean, $\mathrm{m}^{*}$ - mean crowding, $\mathrm{s}^{2} / \mathrm{m}$ - variance to mean ratio.

\begin{tabular}{lccccc}
\hline Species & Abbreviation & $\mathrm{m}$ & $\mathrm{m}^{*}$ & $\mathrm{~s}^{2} / \mathrm{m}$ & $\begin{array}{c}\text { Frequency } \\
(\%)\end{array}$ \\
\hline Plot A & & & & & \\
Medicago lupulina & $\mathrm{Ml}$ & 3.33 & 12.95 & 10.7 & 60 \\
Hypericum perforatum & $\mathrm{Hp}$ & 1.70 & 2.06 & 1.37 & 78 \\
Aster amellus & $\mathrm{Aa}$ & 1.41 & 2.37 & 1.98 & 62 \\
Betula pendula & $\mathrm{Bp}$ & 1.18 & 1.36 & 1.19 & 66 \\
Galium mollugo & $\mathrm{Gm}$ & 0.74 & 5.00 & 5.31 & 27 \\
Linum catharticum & $\mathrm{Lc}$ & 0.40 & 0.55 & 1.16 & 29 \\
Scabiosa ochroleuca & $\mathrm{So}$ & 0.28 & 0.43 & 1.16 & 22 \\
Euphorbia cyparissias & $\mathrm{Ec}$ & 0.27 & 0.15 & 0.89 & 25 \\
& & & & & \\
Plot B & & & & & \\
Brachypodium pinnatum & $\mathrm{Brp}$ & 2.83 & 4.88 & 3.08 & 86 \\
Hypericum perforatum & $\mathrm{Hp}$ & 2.45 & 2.58 & 1.14 & 89 \\
Origanum vulgare & $\mathrm{Ov}$ & 2.01 & 2.29 & 1.29 & 86 \\
Cerinthe minor & $\mathrm{Cm}$ & 0.86 & 2.56 & 2.73 & 30 \\
Teucrium chamaedrys & $\mathrm{Tch}$ & 0.54 & 1.78 & 2.26 & 28 \\
Linum flavum & $\mathrm{Lf}$ & 0.52 & 1.50 & 2.00 & 28 \\
Betula pendula & $\mathrm{Bp}$ & 0.31 & 0.71 & 1.41 & 23 \\
Euphorbia cyparissias & $\mathrm{Ec}$ & 0.29 & 0.41 & 1.14 & 24 \\
\hline
\end{tabular}

area appear in considerable numbers both in vegetation and in the seed bank.

\section{DISCUSSION}

Most of plant-communities-seed banks exhibit the following structure: some of the species are considerably numerous, constituting over $50 \%$ of all diaspores; the remaining species are represented by isolated seeds only (e.g. Symonides 1978; Pirożnikow 1983; Tsuyuzaki 1989; Dessaint et al. 1991; Milberg, Persson 1994; Warr et al. 1994; Garcia-Fayos et al. 1995; Milberg 1995; Csontos et al. 1996; Pakeman, Hay 1996; Kalamees, Zobel 1997). The seed bank of xerothermic grassland is no exception here. In the seed bank of the Biała Góra grassland the highest participation numbers belong to (depending on the vegetation type): A. amellus, B. pendula, B. pinnatum, $H$. perforatum and M. lupulina. There appear a couple of 'cosmopolitan', small-seeded pioneer species whose diaspores can be found in the soil of various plant communities. Among them we can point out the species of the genus Betula and Hypericum (Pirożnikow 1983; Bigwood, Inouye 1988; Kjelsson 1992; Milberg, Hansson 1994; Milberg, Persson 1994; Warr et al. 1994; Milberg 1995; Bekker et al. 1997; Mitchell et al. 1998; Jankowska-Błaszczuk 2000; Chabrerie et al. 2002), whose considerable numbers were present in soil of the examined grassland, too.

In the literature on the subject we may come across the information that $B$. pinnatum does not form a persistent seed bank and the number of caryopses in the soil is usually small (Thompson 1987; Willems 1995; Thompson et al. 1996). This situation results first of all from the intensive pre- and postdispersal predation of its fruits. It seems that the regenerative strategy exhibited by this species is first of all vegetative expansion, for the mass of its underground rhizomes (stolon system) exceeds 2-3 times its aboveground biomass (Willems 1995). In the light of the above data, then, the high number of caryopses of $B$. pinnatum
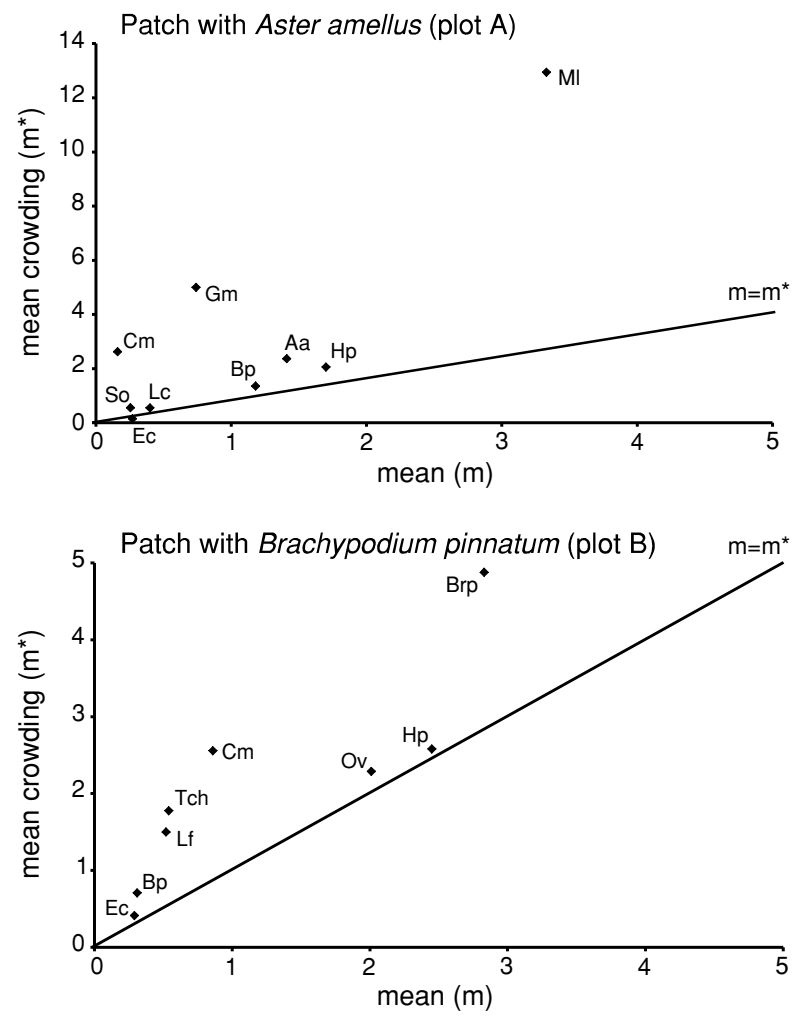

Fig. 3. Mean (m) versus mean crowding $\left(\mathrm{m}^{*}\right)$ - plot A and B; for explanation of abbreviations see Table 3 .

presented in this study may seem surprising. However, this appears to be a passing, short-time effect of the improvement of its condition and fertility resulting from burningout of the grassland, which occurred a year before the carried out research. Schlaepfer (1997) reported the same effect after this type of management. He applied different management regimes (cutting with different frequency, burning and abandonment) to the grassland. The highest number of inflorescences, which was the determinant of the total seed production, was observed on burned plots. The main factor promoting the formation of inforescences seemed to be the absence of litter.

Interestingly, the species most numerous in the seed bank quite often have a relatively small participation in the vegetation (in this study: $H$. perforatum, B. pendula and $M$. lupulina). Additionally, the seed stock in the soil shows a considerably greater species variety than the plant cover. This conclusion does not refer to grasslands only (Thompson 1986; Graham, Hutchings 1988; Milberg, Hansson 1994; Milberg 1995), but it is also true for sand dune plant communities (Symonides 1978) and woodlands (Thompson, Grime 1979; Pirożnikow 1983). It has to be stressed, too, that this study demonstrates that the differences in density and structure of both grassland patches have absolutely no reflection in the quantitative characteristics of the seed bank. In both cases all the measured parameters (seed number, biodiversity and evenness coefficients) are extremely similar. The differences concern the qualitative features: firstly, the species composition of the seed bank, and secondly, the participation of diaspores belonging to particular taxa in the total seed pool.

The Biała Góra xerothermic-grassland species have a clustered spatial organisation of their seed banks. The distribution of anemochores transported from the outside of 

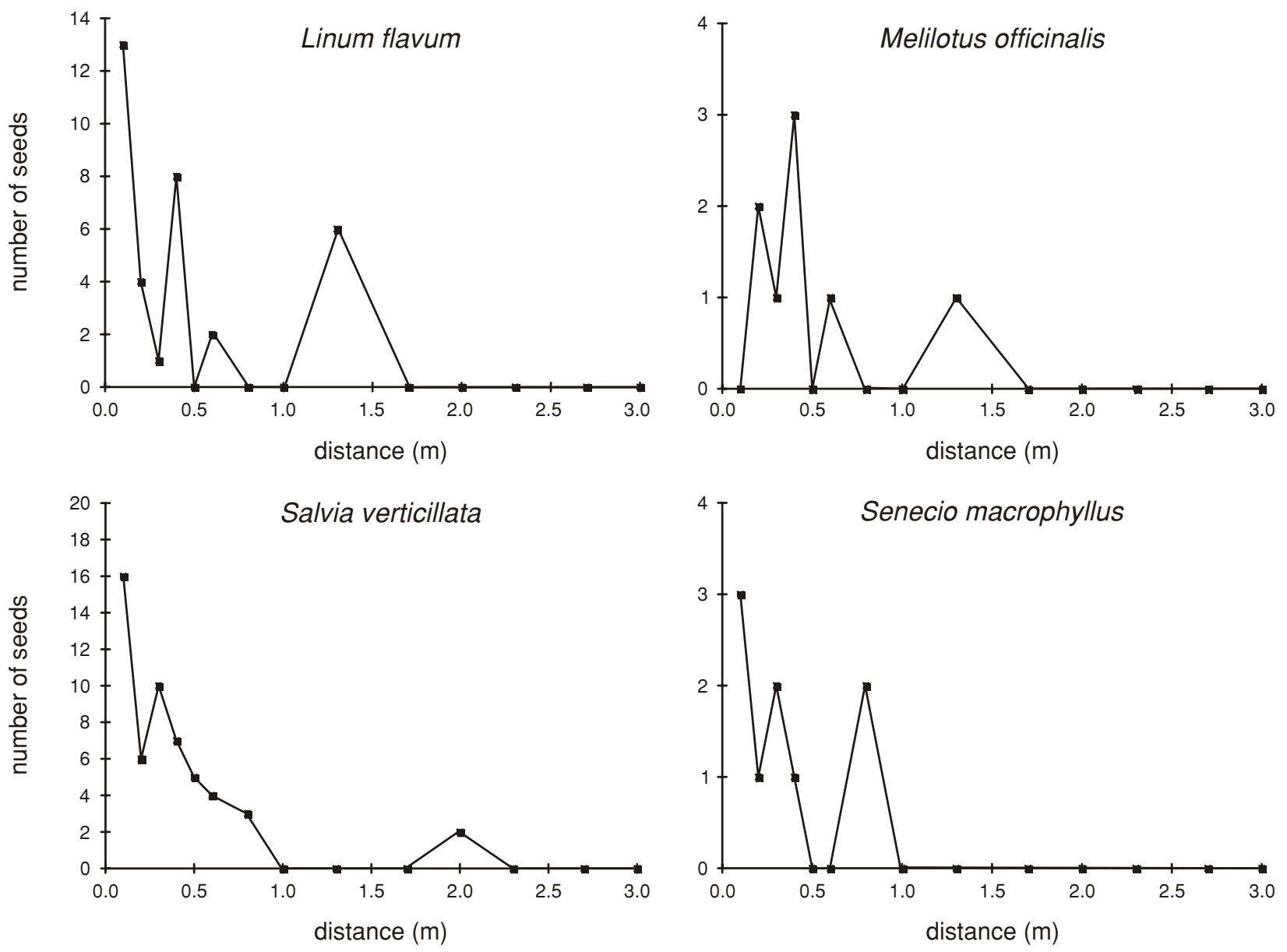

Fig. 4. Relation between distance from the parent plant and the number of seeds in soil.

the examined plant community (H. perforatum and B. pendula) is closer to random to a higher degree than it is the case with seeds of barochores or these anemochores which were produced within the examined grassland (e.g. $A$. amellus, $B$. pinnatum and $M$. lupulina). The clustered spatial structure is typical for the seed bank of many plant communities: dune sand plants (Symonides 1978), deciduous forests (Pirożnikow 1983), grasslands (Verkaar et al. 1983; Thompson 1986; Van Tooren 1988; Rush 1992), plant communities of arable lands, old, abandoned fields and badlands (Bigwood, Inouye 1988; Dessaint et al. 1991; Garcia-Fayos et al. 1995). The most important factor contributing to the creation of seed concentration is their transportation to very small distances from parent plants. Verkaar et al. (1983) concluded, and their conclusion gets further confirmation in the research conducted at the Biała Góra, that in the case of grassland species most of the seeds remain within a distance of 0.3 to $3.5 \mathrm{~m}$ from a fruiting individual. Dispersal distance of anemochorous species (e.g. grassland species Scabiosa columbaria and $S$. ochroleuca diaspores with wing-like structures made by calyx and epicalyx) can be attributed to seed mass and surface structures influencing air resistance (Hensen, Müller 1997). Stem height and wind velocity are the next factors determining the effectiveness of seed dispersal. Release height enables diaspores to tower above the surrounding vegetation and helps to reach longer distances. Horizontal dispersal distances increase overproportionally in relation to wind velocity. It points out that stormy weather may be very important for long-distance seed dispersal (Verkaar et al. 1983; Hensen, Müller 1997). According to Klinkhamer et al. (1988), more than 50\% of cypselas of Cirsium vulgare remain no further than $1 \mathrm{~m}$ from the parent plant, and only $10 \%$ reache the distance greater than $32 \mathrm{~m}$ : these are the seeds that happened to be elevated to considerable heights.

An important question asked by the ecologists studying the seed banks is the volume and number of soil samples ensuring credible results informing on species diversity and the spatial structure of the seed bank. Taking many small samples rather than a few bigger ones is usually recommended (Thompson et al. 1997). However, the concept of "many samples" has never been clearly defined. Thompson (1986) considers 50 soil cores as the absolute minimum, on the condition that there exist no vital contraries. He remarks additionally that if the need should be to limit the amount of the material taken, sample number should be maintained at the expense of sample size. Therefore the number of approximately 20 samples taken by Schenkveld and Verkaar (1984) was estimated by Thompson (1986) as too small. We may assume, then, that a hundred of samples taken for the examination of the seed bank of different patches of xerothermic grassland is a sufficient number guaranteeing credible results.

According to Gross (1990), the extraction of seeds by washing and sieving - the method used in this study - has several advantages over the germination method. It is especially clear when a large number of seed cores must be 


\section{Species diversity}

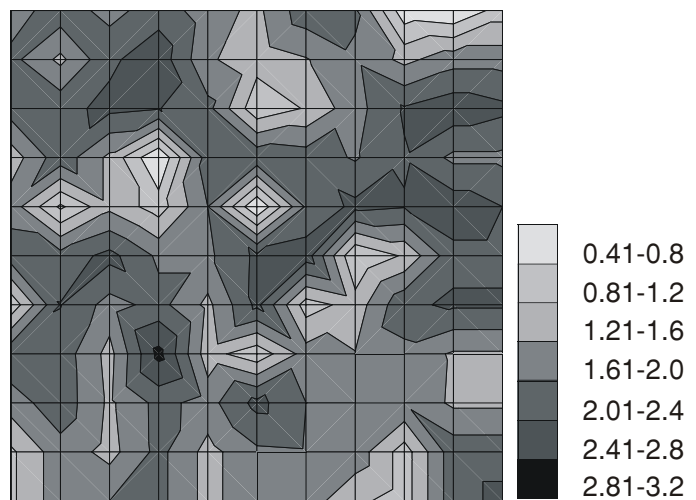

\section{Evenness}

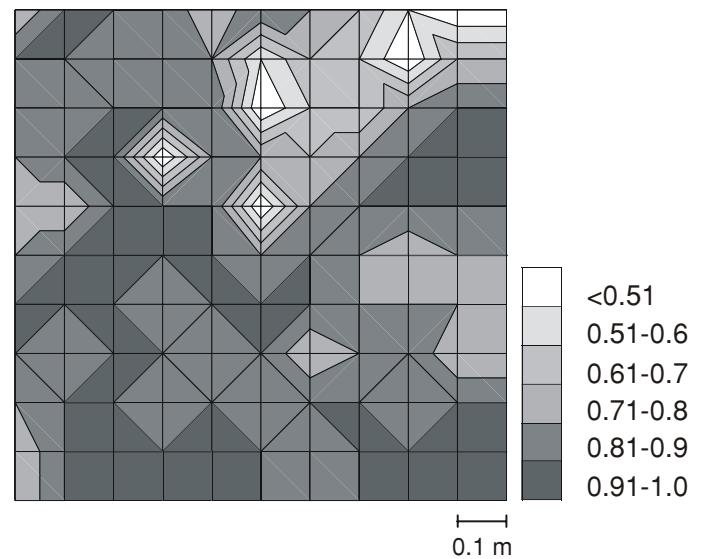

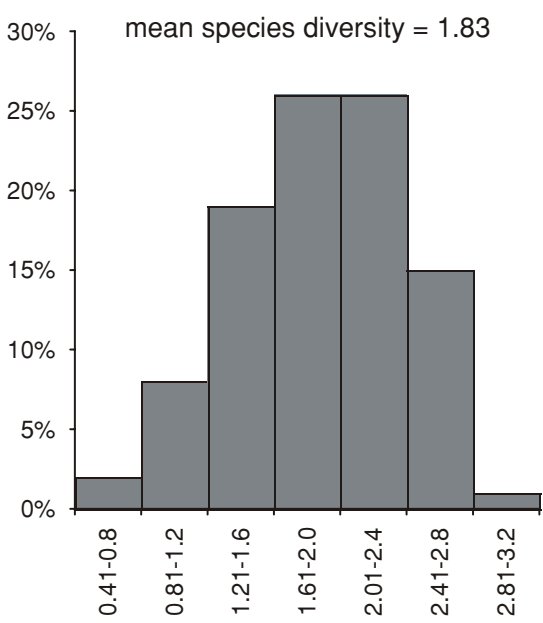

mean evenness $=0.85$

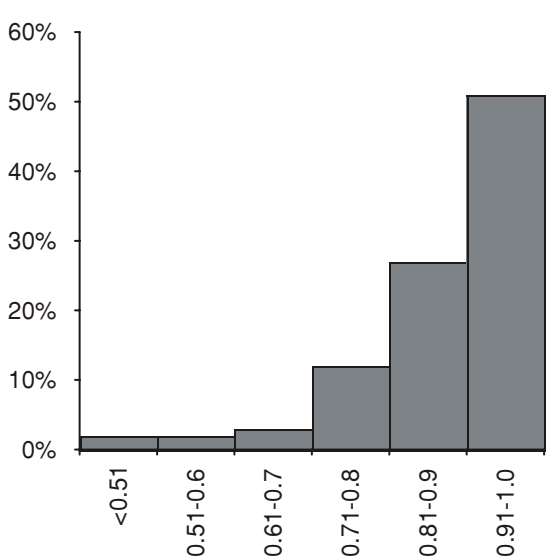

Fig. 5. Spatial variability and frequency distribution of species diversity and evenness indices - patch of lower grassland with dominance of Aster amellus (plot A).

taken. Although this method is time-consuming and small light-coloured seeds can be missed, a big number of cores can be processed and stored. This way work can be spread out over long time.

The seed extraction method must necessarily be accompanied by the seed-germination test or another test for viability of seeds (Thompson et al. 1997). Such a test is indispensable for the accurate estimate of the actual number of the living diaspores because the results obtained with the help of this method are always considerably higher than in the case of using the seedling emergence method (e.g. Gross 1990; Pirożnikow 1983; Falińska 1999). Marked differences in the percentage of viable seeds among the species are typical for this kind of research and they were observed in the studies devoted to the seed banks of various plant communities (Symonides 1978; Gross 1990). The results obtained over all species by Gross (1990) were close to the one arrived at by the author and reached $20-30 \%$.

\section{ACKNOWLEDGMENTS}

I would like to thank prof. Bożenna Czarnecka for verification of thesis of this work and mgr Anna Majewska and mgr Krystyna Kowalska for help in outdoor and laboratory work.

\section{LITERATURE CITED}

BEKKER R.M., VERWEIJ G.L., SMITH R.E.N., REINE R., BAKKER J.P., SCHNEIDER S. 1997. Soil seed banks in European grasslands: does land use affect regeneration perspectives? J. Appl. Ecol. 34: 1293-1310.

BIGWOOD D.W., INOUYE D.W. 1988. Spatial pattern analysis of seed banks: an improved method and optimized sampling. Ecology 69 (2): 497-507.

BURACZYŃSKI J. 1997. Roztocze: budowa, rzeźba, krajobraz. UMCS, Lublin. (in Polish)

CHABRERIE O., ALARD D., TOUZARD B. 2002. Diversité de la végétation et du réservoir de graines du sol dans une pelouse calcicole du nord-ouest de la France. Can. J. Bot. 80 (8): 827-840.

CSONTOS P., HORÁNSZKY A., KALAPOS T., LOKÖS L. 1996. Seed bank of Pinus nigra plantations in dolomite rock grassland habitats, and its implications for restoring grassland vegetation. Ann. Historico-Naturales Musei Nationalis Hungarici 88: 69-77.

CZARNECKA B. 1994. Zbiorowiska Białej Góry koło Tomaszowa Lubelskiego jako siedlisko rzadkich roślin naczyniowych. Chrońmy Przyr. Ojcz. 50 (2): 16-22. (in Polish)

CZARNECKA B. 1995. Biologia i ekologia izolowanych populacji Senecio rivularis (Waldst. et Kit) DC i Senecio umbrosus Waldst. et Kit. UMCS, Lublin. (in Polish)

CZARNECKA B., KUCHARCZYK M. 2001. Senecio macrophyllus M. Bieb. - starzec wielkolistny. In: Kaźmierczakowa 


\section{Species diversity}

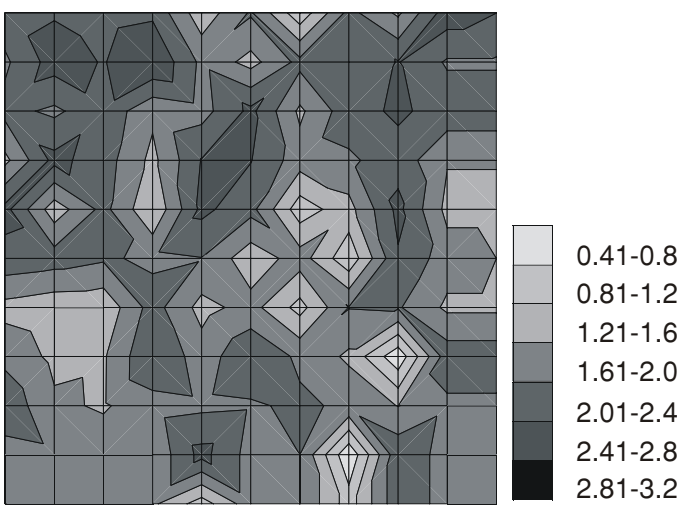

Evenness

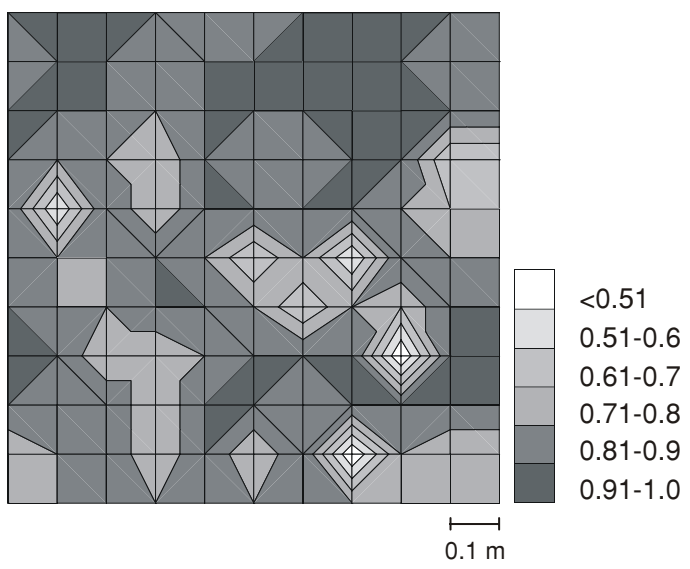

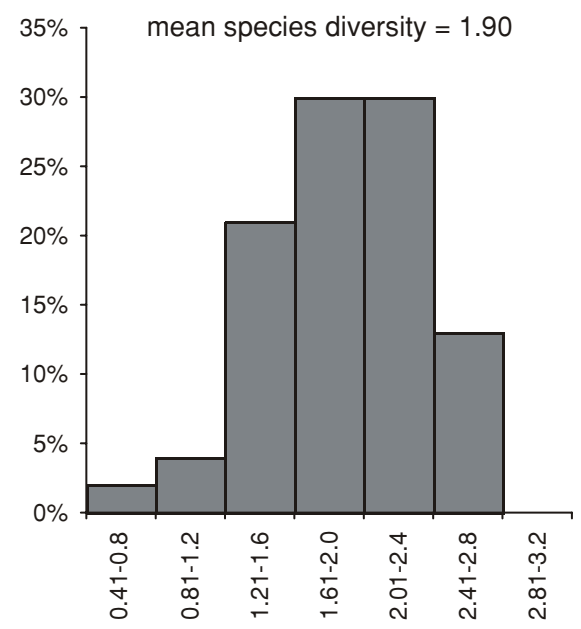

mean evenness $=0.88$

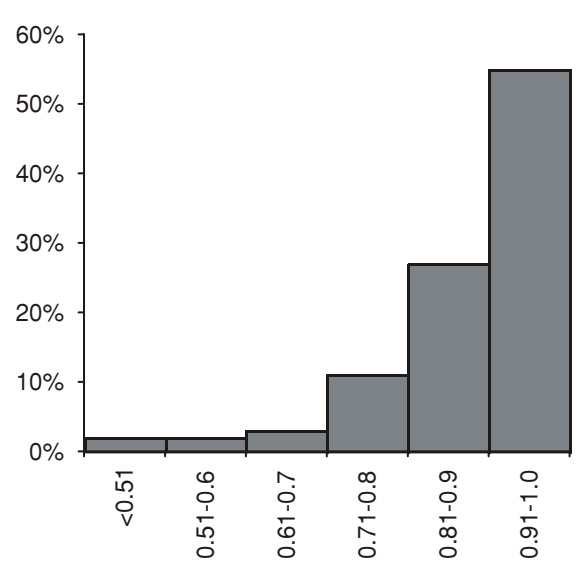

Fig. 6. Spatial variability and frequency distribution of species diversity and evenness indices - patch of higher grassland with dominance of Brachypodium pinnatum (plot $\mathrm{B})$.

R., Zarzycki K. (eds) Polska Czerwona Księga Roślin. Paprotniki i rośliny kwiatowe. Wyd. PAN, Instytut Botaniki im. W. Szafera, Instytut Ochrony Przyrody, Kraków: pp. 375-377. (in Polish)

DESSAINT F., CHADOEUF R., BARRALIS G. 1991. Spatial pattern analysis of weed seeds in the cultivated soil seed bank. J. Appl. Ecol. 28: 721-730.

EDWARDS G.R., CRAWLEY M.J. 1999. Herbivores, seed banks and seedling recruitment in mesic grassland. J. Ecol. 87 (3): 423-435.

FALIŃSKA K., 1999. Seed bank dynamics in abandoned meadows during a 20-year period in the Białowieża National Park. J. Ecol. 87 (3): 461-475.

GARCIA-FAYOS P., RECATALA T.M., CERDÁ A., CALVO A. 1995. Seed population dynamics on badland slopes in Southeastern Spain. J. Veg. Sci. 6: 691-696.

GRAHAM D.J., HUTCHINGS M.J. 1988. Estimation of the seed bank of chalk grassland ley established on former arable land. J. Appl. Ecol. 25: 241-252.

GRANDIN U., RYDIN H. 1998. Attributes of the seed bank after a century of primary succession on islands in Lake Hjalmaren, Sweden. J. Ecol. 86 (2): 293-303.

GROSS K.L. 1990. A comparision of methods for estimating seed numbers in the soil. J. Ecol. 78 (4): 1079-1093.

HENSEN I., MÜLLER C. 1997. Experimental and structural investigations of anemochorous dispersal. Plant Ecol. 133: 169-180 .
JANKOWSKA-BŁASZCZUK M. 2000. Zróżnicowanie banków nasion w naturalnych i antropogenicznie przekształconych zbiorowiskach leśnych. Monographiae Botanicae 88, Łódź. (in Polish with English summary)

KALAMEES R., ZOBEL M. 1997. The seed bank in an Estonian calcareous grassland: comparison of different successional stages. Folia Geobot. Phytotax. 32: 1-14.

KERSHAW K.A. 1978. Ilościowa i dynamiczna ekologia roślin. PWN, Warszawa. (in Polish)

KJELLSSON G. 1992. Seed banks in Danish deciduous forests: species composition, seed influx and distribution pattern in soil. Ecography 15: 86-100.

KLINKHAMER P.G.L., DE JONG T.G., VAN DER MEIJDEN E. 1988. Production, dispersal and predation of seeds in the biennal Cirsium vulgare. J. Ecol. 76 (2): 403-414.

KREBS C.J. 1996. Ekologia. PWN, Warszawa. (in Polish).

KWIATKOWSKA A.J., SYMONIDES E. 1985. Statistical analysis of the phytocoenose homogeneity. I. Distribution of the total species diversity and evenness indices as a homogeneity measure. Acta Soc. Bot. Pol. 54 (4): 449-463.

LLOYD M. 1967. Mean crowding. J. Anim. Ecol. 36: 1-30.

MATUSZKIEWICZ W. 2001. Przewodnik do oznaczania zbiorowisk roślinnych Polski. PWN, Warszawa. (in Polish)

MILBERG P. 1995. Soil seed bank after eighteen years of succession from grassland to forest. Oikos 72: 3-13.

MILBERG P., HANSSON M.L. 1994. Soil seed bank and species turnover in a limestone grassland. J. Veg. Sci. 5: 35-42. 
MILBERG P., PERSSON T.S. 1994. Soil seed bank and species turnover in a limestone grassland. Ann. Bot. Fenn. 31: 155-162.

MIREK Z., PIĘKOŚ-MIRKOWA H., ZAJĄC A., ZAJĄC M. 2002. Flowering plants and pteridophytes of Poland a checklist. W. Szafer Institute of Botany, Polish Academy of Sciences, Kraków.

MITCHELL R.J., MARRS R.H., AULD M.H.D. 1998. A comparative study of the seedbanks of heathland and successional habitats in Dorset, Southern England. J. Ecol. 86 (4): 588-596.

OLACZEK R., WARCHOLIŃSKA A.U. 1999. Ochrona środowiska i żywych zasobów przyrody. Wybrane zagadnienia. Wyd. Uniw. Łódzkiego, Łódź. (in Polish)

PAKEMAN R.J., HAY E. 1996. Heathland seedbanks under braken Pteridium aquilinum (L.) Kuhn and their importance for revegetation after bracken control. J. Env. Manag. 47: 329-339.

PIROŻNIKOW E. 1983. Seed bank in the soil of stabilised ecosystem of a deciduous forest (Tilio-Carpinetum) in the Białowieża National Park. Ekol. Pol. 31 (1): 145-172.

RUSH G. 1992. Spatial pattern of seedling recruitment at two different scales in a limestone grassland. Oikos 65: 433-442.

SCHENKEVELD A.J., VERKAAR H.J. 1984. The ecology of short-lived forbs in chalk grassland: distribution of germinative seeds and its significance for seedling emergence. J. Biogeogr. 11: 251-260.

SOBCZYK M. 1990. Statystyka. Wyd. UMCS, Lublin. (in Polish)

SYMONIDES E. 1978. Numbers, distribution and specific composition of diaspores in the soils of the plant association Spergulo-Corynephoretum. Ekol. Pol. 26 (1): 111-122.

SZAFER W., ZARZYCKI K. 1972. Szata roślinna Polski. PWN, Warszawa. (in Polish)
SCHLAEPFER F. 1997. Influence of management on cover and seed production of Brachypodium pinnatum (L.) Beauv. in calcareous grassland. Bulletin of the Geobotanical Institute ETH 63: 3-10.

THOMPSON K. 1986. Small-scale heterogeneity in the seed bank of an acidic grassland. J. Ecol. 74 (3): 733-738.

THOMPSON K. 1987. Seeds and seed banks. New Phytol. 106 (Suppl.): 23-34.

THOMPSON K., BAKKER J., BEKKER R. 1997. The soil seed banks of North West Europe: methodology, density and longevity. University Press, Cambridge.

THOMPSON K., GRIME J.P. 1979. Seasonal variation in the seed banks of herbaceous species in ten contrasting habitats. J. Ecol. 67 (3): 893-922.

THOMPSON K., HILLIER S.H., GRIME J.P., BOSSARD C.C., BAND S.R. 1996. A functional analysis of limestone grassland community. J. Veg. Sci. 7: 371-380.

TSUYUZAKI S. 1989. Buried seed populations on the Volcano Mt. Usu, Nothern Japan, ten years after 1977-78 eruptions. Ecol. Res. 4: 167-173.

VAN TOOREN B.F. 1988. The fate of seeds after dispersal in chalk grassland: the role of bryophyte layer. Oikos 63: 139-146.

VERKAAR H.J., SCHENKEVELD A.J., VAN DER KLASHORST M.P. 1983. The ecology of short lived forbs in chalk grasslands: dispersal of seeds. New. Phytol. 95: 335-344.

WARR S.J., KENT M., THOMPSON K. 1994. Seed bank composition and variability in five woodlands in South-West England. J. Biogeogr. 21: 151-168.

WILLEMS J.H. 1995. Soil seed bank, seedlings recruitment and actual species composition in an old and isolated chalk grassland site. Folia Geobot. Phytotax. 30: 141-156. 